DOI: 10.17707/AgricultForest.64.2.11

\author{
Maryam POURKARIMI, Shahla MAHMOUDI*, \\ Mohamadhasan MASIHABADI, Ebrahim PAZIRA, Abolfazl MOEINI ${ }^{1}$
}

\title{
POSSIBILITY OF USING LAND COMPONENTS FOR ESTIMATION OF SOIL EROSION: A CASE STUDY OF A WATERSHED OF THE SECOND URBAN PHASE, MASHHAD, KHORASAN PROVINCE
}

\begin{abstract}
SUMMARY
In most parts of Iran, due to population growth, deforestation, over-grazing of pastures and other factors, soil erosion is more than the world's average and increase as time passes. Therefore, its correct evaluation is very important. The Mashhad-Chenaran is the biggest and most important sub-basin of Khorasan, with an extension of about 223989 acres. Two models, the MPSIAC and the Erosion Potential Method - EPM (Gavrilovic, 1972), used for evaluation of sediment amounts and soil erosion stations showed $2.74 \mathrm{t} \mathrm{ha}^{-1}$ per year. However, the MPSIAC model showed $1.56 \mathrm{t} \mathrm{ha}^{-1}$; whereas the EPM model showed larger amounts of $5.73 \mathrm{t} \mathrm{ha}^{-1}$ per year. In soil erosion studies in watersheds, researchers have often introduced hydrological units of work. In this research, physicalgeographical factors such as geological factors, soil type, vegetation, slope were utilized in the erosion estimation models used in addition to the hydrological units in the land components. The present study attempted to measure the erosion and sediment in hydrological units (sub-basins) and land components. The accuracy of estimates of erosion was tested; in order to ensure that the accuracy of the results or possibly the superiority of the homogeneous units to the hydrological units is ensured, it can be used in the same areas in the future.
\end{abstract}

Key words: Erosion, Erosion Potential Method - EPM, Land use, MPSIAC, Sediment.

\section{INTRODUCTION}

Soil is one of the most important natural resources in every country. Soil erosion is a serious issue and can be considered as a big threat for civilized mankind (Kavian et al., 2018; Ahamdi et al., 2011, Hessel and Jetten, 2007, Fanetti, 2007; Hadley, 1984). In recent times, the increase in erosion and its effect on the economy and environment result in a serious problem (Lim et al., 2005). Due to the lack of sufficient and reliable information, regarding the

\footnotetext{
${ }^{1}$ Maryam Pourkarimi, Ebrahim Pazira, Department of Soil Science, Science and Research Branch, Islamic Azad University, Tehran, IRAN. Shahla Mahmoudi (corresponding author: smahmodi@ut.ac.ir), Department of Soil Science, Tehran University, Tehran, IRAN. Mohamadhasan Masihabadi, Soil and water Research Institute of Tehran IRAN, Abolfazl Moeini, Department of watershed management, Science and Research Branch, Islamic Azad University, Tehran, IRAN

Notes: The authors declare that they have no conflicts of interest. Authorship Form signed online.
} 
amounts and kinds of soil erosion in most watersheds in Iran and most other parts of the world, several models have been designed and accomplished to estimate soil erosion and sedimentation. However, the determination of erosion and sedimentation by using available models has some difficulties and problems due to inconsistency and inadaptability in the intended areas. The conflicts in this concern caused researchers to start finding a suitable solution to the amounts of soil erosion and subsequently prevent soil erosion (Ahmadi et al., 2011).

Although soil erosion quality and quantity can be studied with different models, most of them were unsuitable for application. So, it is essential to validate the accuracy and performance of models in different watersheds (Merrit et al., 2003). By comparing MPSIAC, Hydrophysical model with the EPM model, using the GIS tool in Nozhian watershed in Lorestan province, Davari et al. (2005) estimated the quality and quantity of erosion and sedimentation. The result showed that the hydrophysical method, using the EMPSIAC model is more precise compared with the EPM model. The result of proficiency estimation by using different experimental methods to determine erosion and sedimentation in Babol Rood watershed in Mazandaran province indicated that among the seven experimental methods namely MPSIAC, EPM, Fornier, Doglas, Kirkby, Geomorphology and Hydrophysics, the MPSIAC model is the most appropriate model for evaluating erosion and sedimentation (Khosravi et al., 2011; Amiri, 2010; Arekhi and Nazari, 2008).

Big watersheds have been divided into sub-basins in several studies. The main reasons for their dissociation are: circumstance of hydrographic network in watershed, watershed area, damaged areas because of flooding or susceptible areas to flooding and study purposes (Esmaili, 2011). To divide watersheds into hydrologic units, some features were considered such as soil gravel volume, depth of porosity, soil texture, depth and type of limiting layer etc. The soil can be divided into four groups based on the ability of runoff potential namely: Hydrologic group A (very low runoff potential), Hydrologic group B (low runoff potential), Hydrologic group C (high runoff potential), Hydrologic group D (very high runoff potential) (Refahi, 1999).

In the first level, the land type is divided into nine main forms and one extra form, based on slope, phsiography etc. At the second level, each land form is divided into several land types according to topographic features. Again in the lower level, each land type is divided into several land components according to other characteristics like parent materials, vegetation type, soil type etc. (Ayoubi, 2006). From the theoretical viewpoint, it was assumed that land unit components have the highest homogeneity (Bagheri, 2008).

The working units which have been used by researchers in soil erosion studies of watersheds are mainly hydrologic units (Ahmadi, 2009). However, in the present study more variables and influencing factors were used namely: geology, soil type, vegetation, slope; to evaluate the amounts of soil erosion and sediment amounts, because we have accessibility to land unit maps and their land components in most regions in Iran, in order to test the effects of these factors. 
Blinkov and Kostadinov (2010) evaluated the applicability of various erosion risk assessment methods for engineering purposes. The factors taken into consideration depended on scale, various erosion tasks, as well as various sector needs. According to them, the erosion potential method (EPM) was the most suitable on catchment level for the watershed management needs in this region. It was created, developed, and calibrated in Yugoslavia (Gavrilovic, 1972).

This methodology is in use in: Bosnia \& Herzegovina, Bulgaria, Croatia, Czech Republic, Italy, Iran, Montenegro, Macedonia, Serbia and Slovenia (Spalevic et al., 2017a, Spalevic et al., 2017b; Vujacic et al., 2017; Spalevic et al., 2016a, Spalevic et al., 2016b; Tazioli et al., 2015; Barovic et al., 2015; Spalevic et al., 2015; Behzadfar et al., 2014; Spalevic, 2014a; Kostadinov et al., 2014; Spalevic et al., 2014b; Tazioli, 2009; Milevski, 2008; Fustic and Spalevic, 2000; Curovic et al., 1999. The use of this methodology in research on runoff and the intensity of soil erosion have been demonstrated in Montenegro, specifically in the Region of Polimlje (Vujacic et al., 2016; Vujacic et al., 2015; Spalevic et al., 2013a, 2013b, 2013c, 2013d, 2013e, 2012a, 2012b, 2011, Spalevic et al., 2004, 2000a, 2000b, 1999. The EPM is distinguished by its high degree of reliability in calculating sediment yields as well as reservoir sedimentation (Ristic et al., 2011).

\section{MATERIAL AND METHODS}

The study area of Mashhad-Chenaran is the biggest and most important sub-basin of Kashaf Rood, extending 224009 acres. Mahshad-Chenaran is a relatively big steeped plain located between Hezar-Masjed and Binaloud mountains (Fig. 1). This plain is rectangular, with $120 \mathrm{~km}$ in length and $28 \mathrm{~km}$ width extending from the northeast to south east between Hezar-Masjed and Binaloud mountains.

The study area of Mashhad urban phase II was divided into 4 hydrologic groups (Table 2, Fig.2) and 37 sub-basins or hydrologic units (Fig.1, Table 4).

Based on the results of resource assessment and land capability classification, it contains 7 main land types including mountains, hills, plateaus, upper terraces, piedmont plains, flood plains, gravel debris, fan-shaped alluvial gravel, and a miscellaneous type as well as composite and non-arable lands (Fig. 3, Table 6). According to geology, Paleozoic formations such as Lalun and Mila can be found in this area and the middle section includes a quaternary deposit. The diversity of formations is one of the important factors which constitute different soil types and different geomorphological forms, hence the major effect is on soil erosion and sedimentation.

This area has a Mediterranean type of rainfall, with dry season in summers and rainy season in cold winters. Due to sparse vegetation this area is very susceptible to erosion. The average rainfall in Mashhad station is $250 \mathrm{~mm}$. As a result of the type of geology and little vegetation, some sporadic snowing reduces the erosion in this area. In this study, the Gavrilovic (EPM) and MPSIAC models were considered in the estimation of erosion and rates. Based on the 
contemplation of 9 factors in erosion and sediment yield (Table 1) including surface geology, soil, climate, runoff, slope vegetation and land use, the current erosion status and fluvial erosion and sediment transfer were calculated by the MPSIAC model and compared with the models used in Iran (Refahi, 2001). In order to use this model, the watershed was divided into hydrologic units (subbasins) or land unit components or geomorphological homogenous work units based on intended objectives. The used units and their values are presented in Table 1 . The sum of these scores shows the amounts of sediment and erosion intensity in each area (Ahmadi, 2009).

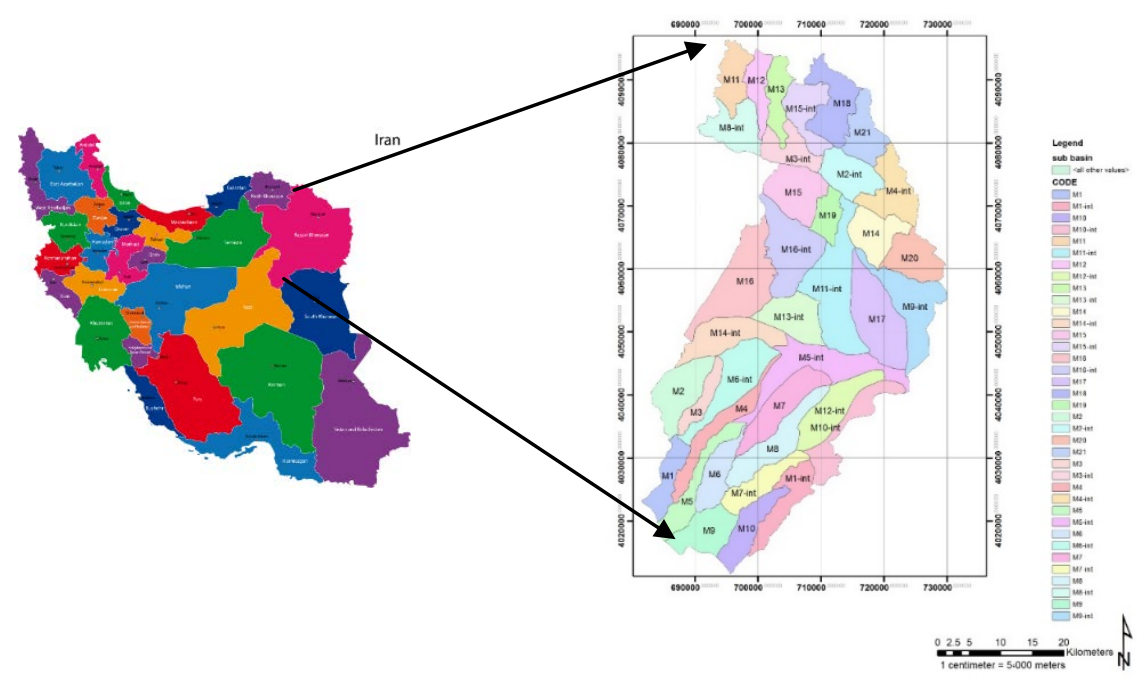

Fig 1: Study Area: Mashhad watershed phase II and intended area location

Table1: The factors and their values used in MPSIAC model

\begin{tabular}{|l|l|l|}
\hline Factors & Calculated points & Definitions \\
\hline Geology & $\mathrm{Y}_{1}=\mathrm{X}_{1}$ & $\mathrm{X}_{1}$ : stone sensitive point \\
\hline Soil & $\mathrm{Y}_{2}=16.6 \mathrm{~K}$ & $\mathrm{~K}:$ erodibility factor in USLE \\
\hline Climate & $\mathrm{Y}_{3}=0.2 \mathrm{X}_{3}$ & $\begin{array}{l}\mathrm{X}_{3}: \text { precipitation intensity with } 2 \text { year interval } \\
\text { return }\end{array}$ \\
\hline Water runoff & $\mathrm{Y} 4=0.006 \mathrm{R}+10 \mathrm{Q}_{\mathrm{p}}$ & $\begin{array}{l}\text { R: annual runoff depth }(\mathrm{mm}), \\
\mathrm{Q}_{\mathrm{p}} \text { : annual specific discharge }\left(\mathrm{CmS} / \mathrm{km}^{2}\right)\end{array}$ \\
\hline Topography & $\mathrm{Y}_{5}=0.33 \mathrm{~S}$ & $\mathrm{~S}$ : average watershed slope $(\%)$ \\
\hline Land cover & $\mathrm{Y}_{6}=0.2 \mathrm{X}_{6}$ & $\mathrm{X}_{6}$ : bare soil $(\%)$ \\
\hline Land use & $\mathrm{Y}_{7}=20-0.2 \mathrm{X}_{7}$ & $\mathrm{X}_{7}$ : canopy cover $(\%)$ \\
\hline Surface erosion & $\mathrm{Y}_{8}=0.25 \mathrm{X}_{8}$ & $\mathrm{X}_{8}$ : points summation in BLM model \\
\hline Gully erosion & $\mathrm{Y}_{9}=0.16 \mathrm{X}_{9}$ & $\mathrm{X}_{9}$ : point of Gully erosion in BLM model \\
\hline $\mathrm{R}=\mathrm{Y}_{1}+\mathrm{Y}_{2}+\mathrm{Y}_{3}+\mathrm{Y}_{4}+\mathrm{Y}_{5}+\mathrm{Y}_{6}+\mathrm{Y}_{7}+\mathrm{Y}_{7}+\mathrm{Y}_{8}+\mathrm{Y}_{9}$ \\
\hline
\end{tabular}


The EPM method is used to determine 3 subjects namely: 1) Erosion intensity and specific erosion, 2) sediment coefficient and specific sediment discharge and 3) total sediment discharge in the determination of soil erosion intensity. Four factors including soil erodibility index (Y), land use coefficient $\left(\mathrm{X}_{\mathrm{a}}\right)$, erosion coefficient $(\Psi)$, and mean slope of the watershed (I) are used in this model.

Considering that there are several effective layers in EPM and MPSIAC, and these layers are used to achieve erosion intensity and sediment yield maps, the first step is to overlap these layers and then by merging these data, the erosion status of the study area can be determined. Map drawing steps are as follows:

1.Georeferencing information layers;

2.Matching watershed and sub-basin boundaries in different layers;

3.Polygoning of target units;

4.Converting polygons to raster layers;

5.Superpositioning and calculating raster layers (9 MPSIAC factors, Table 1 and the factors affecting EPM). Obtaining maps of erosion intensity based on the weight of each layer.

\section{RESULTS AND DISCUSSION}

Mashhad urban watershed phase II (Fig. 1) is divided into 4 hydrologic Groups (Fig. 2, Table 4), 21 main sub-basins and 16 subsidiary sub-basins or 37 Hydrologic Units (Fig.1). Further, this watershed has been divided into 10 land types, 23 land units and 35 land unit components (Fig. 3, Table 7). Sub-basins and land unit components were contemplated as study units to examine erosion rates and intensity.

Table 2: The area of hydrologic Groups in Mashhad watershed phase II

\begin{tabular}{|l|l|}
\hline Hydrologic Groups & Area (ha) \\
\hline A & 35206 \\
\hline B & 76778.448 \\
\hline C & 49170.237 \\
\hline C+D & 1661.268 \\
\hline D & 61193.28 \\
\hline Sum & 224009 \\
\hline
\end{tabular}

The erosion types in the studied area were categorized as follows: Sheet erosion (S) was observed more in most parts of the area. This type of erosion is classified into three (3) namely: $\mathrm{S}_{1}$ with lowest erosion, $\mathrm{S}_{2}$ and severe erosion $\left(S_{3}\right)$. Rill erosion $(R)$ appears because of runoff on the soil surface with not very deep furrows and will disappear by farming operations (Refahi, 1999). This type 
of erosion is divided into 3 classes including $R_{1}$ with furrows less than $10 \mathrm{~cm}$ depth, $R_{2}$ with depth of furrows ranging between 10 to $30 \mathrm{~cm}$, and $R_{3}$ with furrows more than $30 \mathrm{~cm}$ depth. Gully erosion $(\mathrm{G})$ which is an advanced type of rill erosion and waterways or water streams is clear on the land surface (Refahi, 1999).

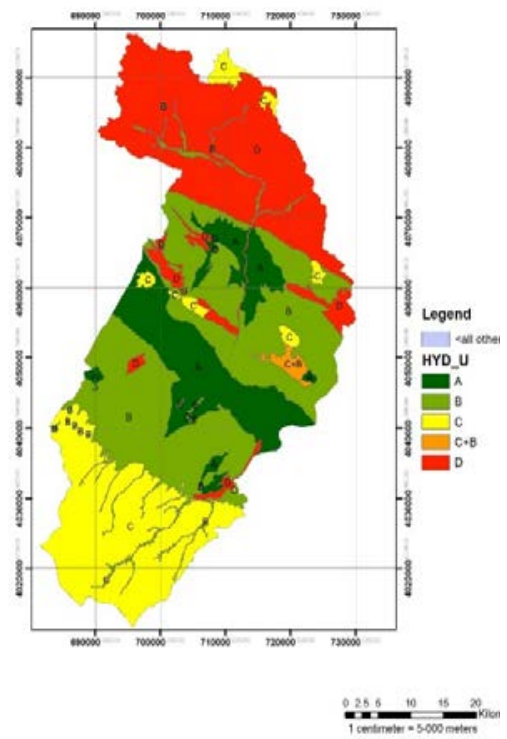

Fig. 2 Hydrological map Groups

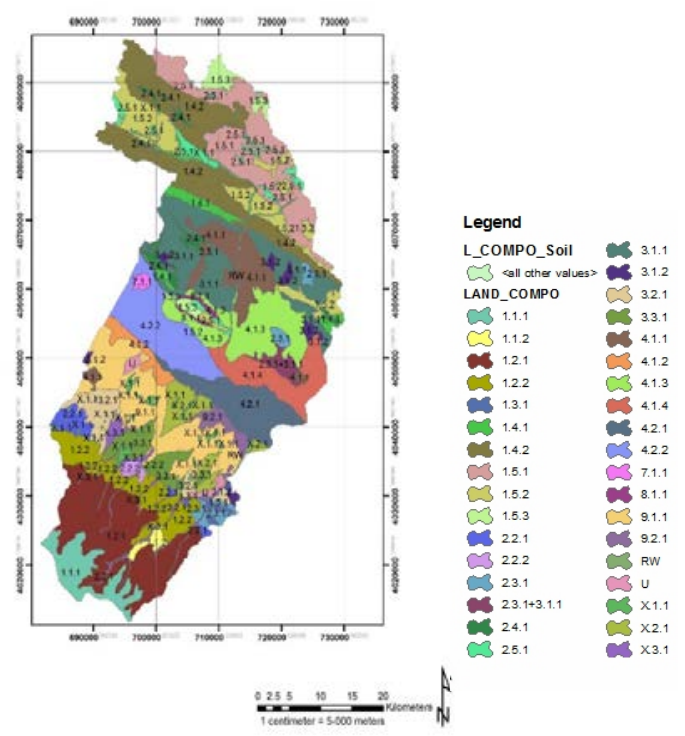

Fig. 3 Land components map

This type can also be divided into 3 classes: $\mathrm{G}_{1}, \mathrm{G}_{2}$ and $\mathrm{G}_{3}$. By using EPM and MPSIAC, erosion was calculated in the studied units and dominant erosion types in sub-basins and land unit components are shown in Tables 4, 5 and 7, respectively. Estimated erosion and sedimentation in work units (Table 3) showed that changing the studied units (sub-basins and land components) has no effect on estimation accuracy.

Table 3: erosion and sediment Rates in Mashhad urban watershed phase II by studied units dissociation

\begin{tabular}{|c|c|c|c|c|c|c|}
\hline \multirow{2}{*}{ Area (ha) } & \multirow{2}{*}{ Studied unit } & \multicolumn{3}{|c|}{$\begin{array}{c}\text { Sediment } \\
\text { (ton.ha }{ }^{-1} \text { per year) }\end{array}$} & \multicolumn{2}{|c|}{$\begin{array}{c}\text { Erosion } \\
\text { (ton.ha }{ }^{-1} \text { per year) }\end{array}$} \\
\hline & & $\begin{array}{l}\text { Hydrometric } \\
\text { stations }\end{array}$ & MPSIAC & EPM & MPSIAC & EPM \\
\hline \multirow[b]{2}{*}{223989.7} & Sub basin & \multirow[b]{2}{*}{2.74} & 1.56 & 5.73 & 3.19 & 9.45 \\
\hline & $\begin{array}{c}\text { Land } \\
\text { Component }\end{array}$ & & 1.50 & - & 3.39 & 9.66 \\
\hline
\end{tabular}

There is a difference between calculated sediment amount by using 2 used models in this study and reported sediment amount in sediment measurement 
stations (Table 3, Diagram 1). The sediment amount calculated using the MPSIAC model is 1.5 ton.ha $^{-1}$ per year which is about half of the reported studies in sediment measurement stations. It shows less estimation in this model, however this variable calculated by EPM was 5.73 ton.ha ${ }^{-1}$ per year which is 2.9 times higher than reported studies and it shows overestimation in this model.

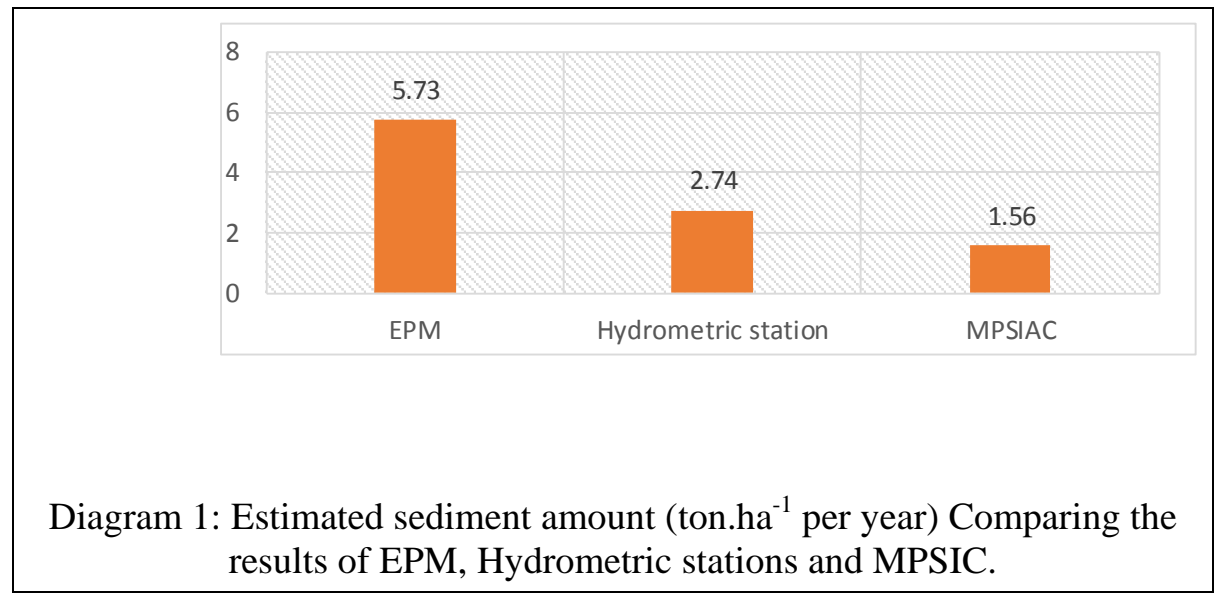

The findings in this study confirm previous studies conducted by Davari et al. (2005), Ahmadi et al. (2011), and Abedini et al. (2013). The erosion level of each sub-basin and the differences of estimation by using EPM and MPSIAC models and dominant erosion types in each sub-basin are shown in Table 4.

Studies conducted in Iran, in relation to this topic include the following research teams lead by: Bagherzade Karimi (1993), Faraji (1994), Tahmasbipour (1994), Shakeri and Balaeepour (1994), Nikjoo (1994), Asadi (1995), Rafahi and Nemati (1995), Sarkhosh (1996), Koupayi (1997), Azamirad (1998), Ghaderi Choukanlou (1998), Bayat (1999), Rafahi (1999); Nabipei Lashkarian (2000), Agharazi and Ghodousi (2001), Bayat et al. (2001), Ghodoosi (2002); Tangestani (2006), Khodabash (2010). In these studies, the MPSIAC model compared to the EPM model or one of the experimental methods was introduced as the more effective model (Davari et al., 2005). Also, in studies which employed GIS, regardless of the result of erosion and sediment yield, the utilization of modern technologies like remote sensing (RS) is recommended because of accuracy and time saving compared to the traditional methods (Rastgou, 2006; Malekian et al., 2012).

A difference between observational estimated sediment and these 2 models (Table 3, Diagram 1) might be found due to the in-acquisition and comprehensiveness of these models with different conditions of watershed. When the study unit defined land components, the length of the longest waterway or water stream will not be calculable by using conventional methods and this parameter cannot be defined in land unit components. This is the reason why the sediment amount is not calculable by the EPM model. The erosion types of the 
land components (Table 5) and estimated erosion by using the EPM and MPSIAC models, soil types, vegetation types and land usage are shown in Table 7. Based on the soil map of Iran (reference), this area is covered dominantly (48.32\%) by shallow soils (Lithic Xerorthens), based on the slope (25\%) they are categorized into class C and D hydrologic groups. The land slope was $25 \%$ and categorized into hydrologic groups $\mathrm{C}$ and D. Mountains and hill types with rock outcrop are dominant and usually there is no vegetation or canopy or low canopy can be observed (Table 7).

Table 4: Amount and types of erosion in each sub basin (ton.ha-1 per year)

\begin{tabular}{|c|c|c|c|c|}
\hline \multirow{2}{*}{ Sub basin } & \multirow{2}{*}{ Area (ha) } & \multicolumn{2}{|c|}{ Erosion (t ha ${ }^{-1}$ year) } & \multirow{2}{*}{ Erosion type } \\
\hline & & MPSIAC & EPM & \\
\hline$M_{1-\text { int }}$ & 5029.73 & 2.98 & 7.64 & $\mathrm{~S}_{1} \mathrm{R}_{2} \mathrm{G}_{1}$ \\
\hline $\mathrm{M}_{2 \text {-int }}$ & 5312.76 & 7.36 & 18.80 & $\mathrm{~S}_{1} \mathrm{R}_{2} \mathrm{G}_{3}$ \\
\hline$M_{3 \text {-int }}$ & 4226.73 & 4.36 & 17.42 & $\mathrm{~S}_{2} \mathrm{R}_{2} \mathrm{G}_{1}$ \\
\hline $\mathrm{M}_{4 \text {-in }} \mathrm{t}$ & 6278.54 & 7.72 & 9.78 & $\mathrm{~S}_{1} \mathrm{R}_{2} \mathrm{G}_{3}$ \\
\hline $\mathrm{M}_{5 \text {-int }}$ & 9570.36 & 1.70 & 2.16 & $\mathrm{~S}_{1} \mathrm{R}_{1}$ \\
\hline $\mathrm{M}_{1}$ & 3935.53 & 4.27 & 12.05 & $\mathrm{~S}_{2} \mathrm{R}_{1} \mathrm{G}_{3}$ \\
\hline $\mathrm{M}_{2}$ & 6576.25 & 1.80 & 8.53 & $\mathrm{~S}_{1} \mathrm{R}_{1}$ \\
\hline $\mathrm{M}_{3}$ & 2729.25 & 2.00 & 7.16 & $\mathrm{~S}_{1} \mathrm{R}_{1} \mathrm{G}_{1}$ \\
\hline $\mathrm{M}_{6 \text {-int }}$ & 7820.80 & 1.51 & 4.29 & $\mathrm{~S}_{1} \mathrm{R}_{1}$ \\
\hline $\mathrm{M}_{4}$ & 5119.68 & 2.78 & 9.28 & $\mathrm{~S}_{1} \mathrm{R}_{1} \mathrm{G}_{1}$ \\
\hline $\mathrm{M}_{5}$ & 5013.32 & 3.96 & 12.92 & $\mathrm{~S}_{2} \mathrm{G}_{1}$ \\
\hline $\mathrm{M}_{6}$ & 4540.47 & 3.70 & 7.72 & $\mathrm{~S}_{2} \mathrm{G}_{1}$ \\
\hline $\mathrm{M}_{7}$ & 6663.45 & 1.56 & 9.02 & $\mathrm{~S}_{1} \mathrm{R}_{2}$ \\
\hline $\mathrm{M}_{8}$ & 6815.01 & 2.53 & 9.62 & $\mathrm{~S}_{1} \mathrm{R}_{1} \mathrm{G}_{1}$ \\
\hline $\mathrm{M}_{9}$ & 5450.10 & 4.62 & 12.32 & $\mathrm{~S}_{2} \mathrm{R}_{1} \mathrm{G}_{1}$ \\
\hline$M_{7-\text { int }}$ & 4525.03 & 3.19 & 10.51 & $\mathrm{~S}_{1} \mathrm{R}_{2} \mathrm{G}_{1}$ \\
\hline $\mathrm{M}_{10}$ & 4994.99 & 4.10 & 7.16 & $\mathrm{~S}_{2} \mathrm{R}_{1} \mathrm{G}_{1}$ \\
\hline $\mathrm{M}_{11}$ & 4250.62 & 4.81 & 13.20 & $\mathrm{~S}_{2} \mathrm{R}_{1} \mathrm{G}_{1}$ \\
\hline$M_{8 \text {-int }}$ & 5440.12 & 5.55 & 18.90 & $\mathrm{~S}_{1} \mathrm{R}_{2} \mathrm{G}_{2}$ \\
\hline $\mathrm{M}_{12}$ & 3446.04 & 5.84 & 14.70 & $\mathrm{~S}_{1} \mathrm{R}_{1} \mathrm{G}_{2}$ \\
\hline $\mathrm{M}_{13}$ & 3750.15 & 5.72 & 16.44 & $\mathrm{~S}_{1} \mathrm{R}_{1} \mathrm{G}_{2}$ \\
\hline $\mathrm{M}_{20}$ & 5415.62 & 3.48 & 27.50 & $\mathrm{~S}_{2} \mathrm{R}_{2}$ \\
\hline $\mathrm{M}_{15}$ & 6597.36 & 4.85 & 24.56 & $\mathrm{~S}_{2} \mathrm{R}_{2} \mathrm{G}_{2}$ \\
\hline$M_{9 \text {-int }}$ & 8588.61 & 2.98 & 8.03 & $\mathrm{~S}_{1} \mathrm{R}_{2} \mathrm{G}_{1}$ \\
\hline $\mathrm{M}_{16}$ & 11333.53 & 1.44 & 4.55 & $\mathrm{~S}_{1} \mathrm{R}_{1}$ \\
\hline $\mathrm{M}_{10 \text {-int }}$ & 5507.97 & 1.95 & 7.38 & $\mathrm{~S}_{1} \mathrm{R}_{1} \mathrm{G}_{1}$ \\
\hline $\mathrm{M}_{11 \text {-int }}$ & 12059.95 & 2.73 & 5.55 & $\mathrm{~S}_{1} \mathrm{R}_{2} \mathrm{G}_{1}$ \\
\hline $\mathrm{M}_{17}$ & 10041.66 & 1.74 & 2.88 & $\mathrm{~S}_{2} \mathrm{R}_{2}$ \\
\hline$M_{12 \text {-int }}$ & 6462.16 & 1.42 & 4.95 & $\mathrm{~S}_{1} \mathrm{R}_{1}$ \\
\hline$M_{13-\text { int }}$ & 5806.96 & 1.36 & 1.47 & $\mathrm{~S}_{1} \mathrm{R}_{1}$ \\
\hline $\mathrm{M}_{14 \text {-int }}$ & 6727.10 & 1.41 & 3.58 & $\mathrm{~S}_{1} \mathrm{R}_{1}$ \\
\hline M21 & 4928.14 & 3.64 & 4.92 & $\mathrm{~S}_{1} \mathrm{R}_{1} \mathrm{G}_{1}$ \\
\hline$M_{15-\text { int }}$ & 5020.31 & 4.25 & 13.10 & $\mathrm{~S}_{2} \mathrm{R}_{1} \mathrm{G}_{1}$ \\
\hline $\mathrm{M}_{18}$ & 6834.11 & 3.97 & 9.29 & $\mathrm{~S}_{1} \mathrm{R}_{1} \mathrm{G}_{1}$ \\
\hline$M_{16-\text { int }}$ & 9014.04 & 2.23 & 11.14 & $\mathrm{~S}_{1} \mathrm{R}_{2} \mathrm{G}_{1}$ \\
\hline $\mathrm{M}_{14}$ & 5301.95 & 6.38 & 10.43 & $\mathrm{~S}_{2} \mathrm{R}_{2} \mathrm{G}_{2}$ \\
\hline $\mathbf{M}_{19}$ & 2880.64 & 3.90 & 10.62 & $\mathrm{~S}_{2} \mathrm{R}_{2} \mathrm{G}_{2}$ \\
\hline
\end{tabular}


Table 5: Types of erosion in each land unit components

\begin{tabular}{|c|c|c|c|c|c|}
\hline $\begin{array}{c}\text { Land } \\
\text { Component }\end{array}$ & Erosion Type & $\begin{array}{l}\text { Land } \\
\text { Compone } \\
\text { nt }\end{array}$ & $\begin{array}{l}\text { Erosion } \\
\text { Type }\end{array}$ & $\begin{array}{c}\text { Land } \\
\text { Component }\end{array}$ & Erosion Type \\
\hline 1.1.1 & $\begin{array}{l}\mathrm{S}_{2} \mathrm{R}_{1} \mathrm{G}_{1}-\mathrm{S}_{2} \mathrm{G}_{1^{-}} \\
\mathrm{S}_{1} \mathrm{R}_{1} \mathrm{G}_{1}\end{array}$ & 3.1 .1 & $\begin{array}{l}\mathrm{S}_{1} \mathrm{R}_{2} \mathrm{G}_{1^{-}} \\
\mathrm{S}_{2} \mathrm{R}_{2}{ }^{-} \\
\mathrm{S}_{2} \mathrm{R}_{2} \mathrm{G}_{2^{-}} \\
\mathrm{S}_{1} \mathrm{R}_{2} \mathrm{G}_{3^{-}} \\
\mathrm{S}_{1} \mathrm{R}_{1}\end{array}$ & 7.1.1 & $\mathrm{S}_{1} \mathrm{R}_{1}$ \\
\hline 1.1 .2 & $\mathrm{~S}_{1} \mathrm{R}_{2} \mathrm{G}_{1}-\mathrm{S}_{2} \mathrm{R}_{1} \mathrm{G}_{1}$ & 3.1 .2 & $\begin{array}{l}\mathrm{S}_{1} \mathrm{R}_{2} \mathrm{G}_{1^{-}} \\
\mathrm{S}_{2} \mathrm{R}_{2} \mathrm{G}_{2^{-}} \\
\mathrm{S}_{2} \mathrm{R}_{2}\end{array}$ & 8.1.1 & $\mathrm{S}_{1} \mathrm{R}_{2} \mathrm{G}_{1}-\mathrm{S}_{1} \mathrm{R}_{1}$ \\
\hline 1.2.1 & $\begin{array}{l}\mathrm{S}_{1} \mathrm{R}_{2} \mathrm{G}_{1^{-}} \\
\mathrm{S}_{2} \mathrm{R}_{1} \mathrm{G}_{1^{-}} \\
\mathrm{S}_{1} \mathrm{R}_{1} \mathrm{G}_{1^{-}}-\mathrm{S}_{1} \mathrm{R}_{1^{-}} \\
\mathrm{S}_{2} \mathrm{G}_{1}-\mathrm{S}_{1} \mathrm{R}_{2}\end{array}$ & 3.2.1 & $\begin{array}{l}\mathrm{S}_{1} \mathrm{R}_{1-} \\
\mathrm{S}_{1} \mathrm{R}_{1} \mathrm{G}_{1}\end{array}$ & 9.1 .1 & $\begin{array}{l}\mathrm{S}_{1} \mathrm{R}_{1}-\mathrm{S}_{1} \mathrm{R}_{1} \mathrm{G}_{1^{-}} \\
\mathrm{S}_{1} \mathrm{R}_{2}\end{array}$ \\
\hline 1.2 .2 & $\begin{array}{l}\mathrm{S}_{1} \mathrm{R}_{2} \mathrm{G}_{1^{-}} \\
\mathrm{S}_{2} \mathrm{R}_{1} \mathrm{G}_{1^{-}} \mathrm{S}_{1} \mathrm{R}_{1^{-}} \\
\mathrm{S}_{1} \mathrm{R}_{1} \mathrm{G}_{1^{-}} \mathrm{S}_{2} \mathrm{G}_{1^{-}} \\
\mathrm{S}_{1} \mathrm{R}_{2}\end{array}$ & 3.3.1 & $\begin{array}{l}\mathrm{S}_{1} \mathrm{R}_{1^{-}} \\
\mathrm{S}_{1} \mathrm{R}_{1} \mathrm{G}_{1^{-}} \\
\mathrm{S}_{2} \mathrm{G}_{1}-\mathrm{S}_{1} \mathrm{R}_{2}\end{array}$ & 9.2 .1 & $\mathrm{~S}_{1} \mathrm{R}_{1}-\mathrm{S}_{1} \mathrm{R}_{1} \mathrm{G}_{1}$ \\
\hline 1.3.1 & $\begin{array}{l}\mathrm{S}_{1} \mathrm{R}_{1} \mathrm{G}_{1^{-}} \\
\mathrm{S}_{1} \mathrm{R}_{2} \mathrm{G}_{1^{-}}\end{array}$ & 4.1.1 & $\begin{array}{l}\mathrm{S}_{1} \mathrm{R}_{1^{-}} \\
\mathrm{S}_{2} \mathrm{R}_{2-} \\
\mathrm{S}_{1} \mathrm{R}_{2} \mathrm{G}_{2}\end{array}$ & X.1.1 & $\begin{array}{l}S_{1} R_{1} G_{1}-S_{1} R_{1-} \\
S_{1} R_{2}\end{array}$ \\
\hline 1.4.1 & $\begin{array}{l}\mathrm{S}_{2} \mathrm{R}_{2} \mathrm{G}_{2}- \\
\text { S1R2G1- } \mathrm{S}_{1} \mathrm{R}_{1}\end{array}$ & 4.1.2 & $\mathrm{S}_{1} \mathrm{R}_{1}$ & X.2.1 & $\begin{array}{l}\mathrm{S}_{1} \mathrm{R}_{1^{-}} \mathrm{S}_{1} \mathrm{R}_{1} \mathrm{G}_{1^{-}} \\
\mathrm{S}_{1} \mathrm{R}_{2}\end{array}$ \\
\hline 1.4 .2 & $\begin{array}{l}\mathrm{S}_{1} \mathrm{R}_{2} \mathrm{G}_{1^{-}} \\
\mathrm{S}_{2} \mathrm{R}_{1} \mathrm{G}_{1^{-}} \\
\mathrm{S}_{1} \mathrm{R}_{1} \mathrm{G}_{1^{-}} \\
\mathrm{S}_{1} \mathrm{R}_{1} \mathrm{G}_{2}-\mathrm{S}_{2} \mathrm{R}_{2} \mathrm{G}_{1}\end{array}$ & 4.1 .3 & $\begin{array}{l}\mathrm{S}_{1} \mathrm{R}_{2} \mathrm{G}_{1}- \\
\mathrm{S}_{2} \mathrm{R}_{2}\end{array}$ & X.3.1 & $\begin{array}{l}\mathrm{S}_{1} \mathrm{R}_{1} \mathrm{G}_{1}-\mathrm{S}_{1} \mathrm{R}_{1^{-}} \\
\mathrm{S}_{2} \mathrm{G}_{1}\end{array}$ \\
\hline 1.5.1 & $\begin{array}{l}\mathrm{S}_{1} \mathrm{R}_{2} \mathrm{G}_{1}- \\
\mathrm{S}_{1} \mathrm{R}_{1} \mathrm{G}_{2}-\mathrm{S}_{2} \mathrm{R}_{2^{-}} \\
\mathrm{S}_{1} \mathrm{R}_{1} \mathrm{G}_{1}-\mathrm{S}_{2} \mathrm{R}_{2} \mathrm{G}_{2}\end{array}$ & 4.1.4 & $\begin{array}{l}\mathrm{S}_{1} \mathrm{R}_{1^{-}} \\
\mathrm{S}_{1} \mathrm{R}_{2} \mathrm{G}_{1^{-}} \\
\mathrm{S}_{2} \mathrm{R}_{2}\end{array}$ & & \\
\hline 1.5 .2 & 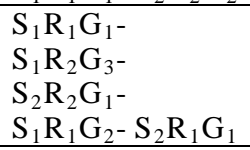 & 4.2 .1 & $\begin{array}{l}\mathrm{S}_{1} \mathrm{R}_{1} \mathrm{G}_{1^{-}} \\
\mathrm{S}_{1} \mathrm{R}_{1}-\mathrm{S}_{1} \mathrm{R}_{2}\end{array}$ & & \\
\hline 1.5 .3 & $\begin{array}{l}\mathrm{S}_{1} \mathrm{R}_{1} \mathrm{G}_{1^{-}} \\
\mathrm{S}_{1} \mathrm{R}_{2} \mathrm{G}_{1^{-}} \\
\mathrm{S}_{2} \mathrm{R}_{1} \mathrm{G}_{1}-\mathrm{S}_{1} \mathrm{R}_{1}\end{array}$ & 4.2 .2 & $\mathrm{~S}_{1} \mathrm{R}_{1}$ & & \\
\hline 2.2.1 & $\begin{array}{l}\mathrm{S}_{1} \mathrm{R}_{2} \mathrm{G}_{1^{-}}-\mathrm{S}_{1} \mathrm{R}_{1^{-}} \\
\mathrm{S}_{1} \mathrm{R}_{1} \mathrm{G}_{1}\end{array}$ & & & & \\
\hline 2.2 .2 & $\mathrm{~S}_{2} \mathrm{G}_{1}-\mathrm{S}_{1} \mathrm{R}_{2}$ & & & & \\
\hline 2.3.1 & 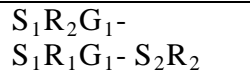 & & & & \\
\hline 2.4 .1 & 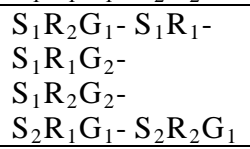 & & & & \\
\hline 2.5 .1 & $\begin{array}{l}\mathrm{S}_{1} \mathrm{R}_{2} \mathrm{G}_{1^{-}} \\
\mathrm{S}_{1} \mathrm{R}_{2} \mathrm{G}_{3^{-}} \\
\mathrm{S}_{1} \mathrm{R}_{1} \mathrm{G}_{1^{-}} \\
\mathrm{S}_{2} \mathrm{R}_{1} \mathrm{G}_{1^{-}} \\
\mathrm{S}_{1} \mathrm{R}_{1} \mathrm{G}_{2^{-}} \\
\mathrm{S}_{1} \mathrm{R}_{2} \mathrm{G}_{2^{-}} \mathrm{S}_{2} \mathrm{R}_{2} \mathrm{G}_{1}\end{array}$ & & & & \\
\hline
\end{tabular}


Based on the similarity of soil types, similar land types and being rocky, having many outcrops in these lands, high slope and low vegetation are the main factors of the high erosion rate. EPM and MPSIAC have been innovated in those countries with different climate and geology attributes. Hence, the coefficients and effective factors in erosion does not correspond to conditions in Iran completely.

For example, in the EPM model, the rock and soil sensitivity to erosion due to the lack of uniformity of weather conditions, weathering and natural erosion of rock and geological formations, as well as differences in land use and vegetation type, have very high values for erosion and are far from reality. In the MPSIAC model, to determine the second effective factor of erosion (soil factor), soil erodibility coefficient $(\mathrm{K})$ was used in the global erosion equation. In this model, the rock outcrop level and its effect on estimation of erosion are not considered and this can affect high calculated erosion in land unit components (mountains and hills). Furthermore, the percentage of canopy can be considered as land use index. This index is suitable for pastures and is not suitable for arable and gardens which have specific canopy (Ahmadi, 2011).

The homogeneity of studied units is very important in determining the accuracy of the estimated erosion amounts in the Otan sub-basin $\left(\mathrm{M}_{16}\right)$, with 11333.53 hectares which contains $5.06 \%$ of the total studied area (Fig. 4), has been dissociated into 10 land unit components (Table 6). Based on information in Table 4, erosion type in this hydrologic Unit $\left(\mathrm{M}_{16}\right) \mathrm{S}_{1} \mathrm{R}_{1}$ showed low sheet and rill erosions. Table -5 shows the different types of erosion in the Otan sub-basins.

There are different erosion types in each land component of the Otan subbasin $\left(\mathrm{M}_{16}\right)$ (Fig. 4, Table 6$)$. It is necessary to attend to erosion types numbers to reduce erosion in land usage. If our focus is on sub-basins, excess erosion in a small expanse of land will not be important.

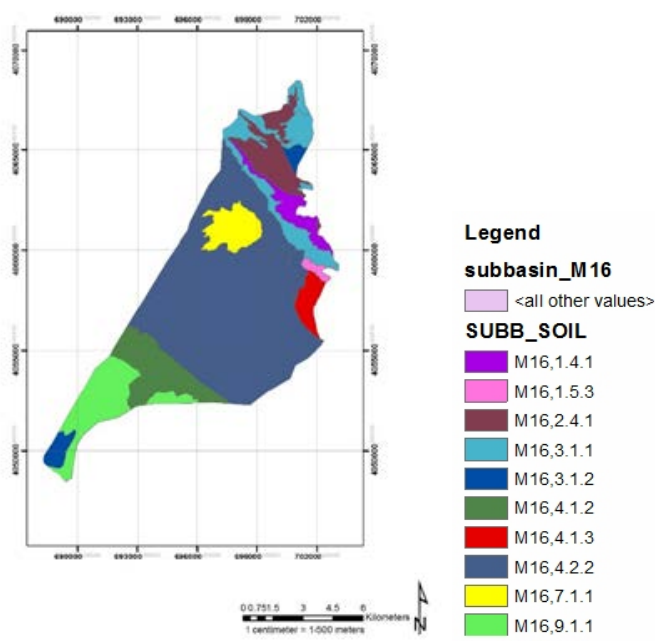

Fig. 4 Map of Otan sub basin ( $\left.\mathrm{M}_{16}\right)$, dissociation of land components 
In the Otan sub-basin $\left(M_{16}\right)$, erosion type is defined as $S_{1} R_{1}$ (Table 4), however rill erosion $\left(\mathrm{R}_{2}\right)$ with 10 to $30 \mathrm{~cm}$ depth and moderate gully erosion $\left(G_{2}\right)$ with 1 to $3 \mathrm{~m}$ width were also observed. Furthermore, gullies in this group affected 25 to $50 \%$ of the total area (Refahi, 1999). Soil erosion can be prevented or limited by giving adequate attention to erosion types, even in a small expanse of land and designation of suitable usage.

Table 6: The amount and types of erosion in Otan sub basin (M16) by dissociating the land components

\begin{tabular}{|c|c|c|c|c|}
\hline $\begin{array}{c}\text { Sub } \\
\text { basin }\end{array}$ & $\begin{array}{c}\text { Land } \\
\text { components }\end{array}$ & $\begin{array}{c}\text { Erosion(ton/ha.year) } \\
\text { MPSIAC }\end{array}$ & Erosion type & Soil type \\
\hline \multirow{10}{*}{$\begin{array}{r}\text { Otan } \\
\left(\mathbf{M}_{16}\right)\end{array}$} & 1.4 .1 & 1.45 & $\begin{array}{l}\mathrm{S}_{2} \mathrm{R}_{2} \mathrm{G}_{2}- \\
\mathrm{S}_{1} \mathrm{R}_{2} \mathrm{G}_{1}-\mathrm{S}_{1} \mathrm{R}_{1}\end{array}$ & Lithic Xerorthents \\
\hline & 1.5 .3 & 1.35 & $\begin{array}{l}\mathrm{S}_{1} \mathrm{R}_{1} \mathrm{G}_{1^{-}} \\
\mathrm{S}_{1} \mathrm{R}_{2} \mathrm{G}_{1^{-}} \\
\mathrm{S}_{2} \mathrm{R}_{1} \mathrm{G}_{1}-\mathrm{S}_{1} \mathrm{R}_{1}\end{array}$ & Lithic Xerorthents \\
\hline & 2.4 .1 & 1.44 & $\begin{array}{l}\mathrm{S}_{1} \mathrm{R}_{2} \mathrm{G}_{1}-\mathrm{S}_{1} \mathrm{R}_{1^{-}} \\
\mathrm{S}_{1} \mathrm{R}_{1} \mathrm{G}_{2^{-}} \\
\mathrm{S}_{1} \mathrm{R}_{2} \mathrm{G}_{2^{-}} \\
\mathrm{S}_{2} \mathrm{R}_{1} \mathrm{G}_{1^{-}} \\
\mathrm{S}_{2} \mathrm{R}_{2} \mathrm{G}_{1}\end{array}$ & Lithic Xerorthents \\
\hline & 3.1.1 & 1.41 & $\begin{array}{l}\mathrm{S}_{1} \mathrm{R}_{2} \mathrm{G}_{1}-\mathrm{S}_{2} \mathrm{R}_{2}- \\
\mathrm{S}_{2} \mathrm{R}_{2} \mathrm{G}_{2^{-}} \\
\mathrm{S}_{1} \mathrm{R}_{2} \mathrm{G}_{3}-\mathrm{S}_{1} \mathrm{R}_{1}\end{array}$ & $\begin{array}{l}\text { Xeric } \\
\text { Hoplogypsids }\end{array}$ \\
\hline & 3.1 .2 & 1.41 & $\begin{array}{l}\mathrm{S}_{1} \mathrm{R}_{2} \mathrm{G}_{1^{-}} \\
\mathrm{S}_{2} \mathrm{R}_{2} \mathrm{G}_{2}-\mathrm{S}_{2} \mathrm{R}_{2}\end{array}$ & $\begin{array}{l}\text { Xeric } \\
\text { Hoplogypsids }\end{array}$ \\
\hline & 4.1 .2 & 1.56 & $\mathrm{~S}_{1} \mathrm{R}_{1}$ & $\begin{array}{l}\text { Xeric } \\
\text { Hoplogypsids }\end{array}$ \\
\hline & 4.1 .3 & 1.51 & $\mathrm{~S}_{1} \mathrm{R}_{2} \mathrm{G}_{1}-\mathrm{S}_{2} \mathrm{R}_{2}$ & $\begin{array}{l}\text { Xeric } \\
\text { Hoplogypsids }\end{array}$ \\
\hline & 4.2 .2 & 1.39 & $\mathrm{~S}_{1} \mathrm{R}_{1}$ & $\begin{array}{l}\text { Typic } \\
\text { Haplocambids }\end{array}$ \\
\hline & 7.1.1 & 1.62 & $\mathrm{~S}_{1} \mathrm{R}_{1}$ & $\begin{array}{l}\text { Sodic } \\
\text { Haplocambids }\end{array}$ \\
\hline & 9.1 .1 & 1.53 & $\begin{array}{l}S_{1} R_{1}-S_{1} R_{1} G_{1-} \\
S_{1} R_{2}\end{array}$ & Xeric Torrifluvent \\
\hline
\end{tabular}

Erosion is high as a result of the soil type (Lithic Xerorthents) and similarity of land types (mountain and hill) in the hydrologic group D, and because of high rock outcrop and low canopy or no canopy (Table 7). The mountains (1.4.1،1.4.2،1.5.1،1.5.2) constituted a salty formation with Red bed and gypsum and in some parts contained conglomerate (1.4.1) and in some parts included valleys with Mozdouran parental material (1.4.2) (Table 7). Another part of the hydrologic group D contains the Mozdouran formation (2.5.1, 1.5.2, 1.5.1) (Table 7). One of the reasons for the high amount of erosion in these areas 
is probably the ineffectiveness and inappropriateness of the EPM and MPSIAC models for this study area.

\section{CONCLUSIONS}

In general, erosion factors in the researched area refer to high slope in folding, texture of parent material, geological formations, rainfall regime, the premature grazing, and the excess capacity, and untechnical exploitation such as: cultivation in high slopes, plowing in the direction of slope and no consideration to crop rotation. The highest amount of erosion occurs in gypsum formations, which naturally forms due to loosening, and also the high dissolution coefficient, erosion acts physically. Preventing and reducing erosion in these areas is difficult but necessary. Due to the aristocracy of these lands to agricultural lands and also the passage of water, it can lead to degradation and low land salinity.

Unfortunately, the minor slopes of these heights have been cultivated and plowed due to the provision of more soil and conditions for erosion. Dry farming in a part of the land, especially in high slope lands, is one of the most effective factors in land degradation, erosion and sediment yield. Considering the importance of dry farming and technical principles in these lands can be very effective in reducing erosion. Also, the determination of land suitability and land use change, inappropriate for utilization, can be an important step towards sustainable land use.

\section{REFERENCES}

Abedini, M. S, Shabrang. A, Esmaeili., (2013): The Evaluation of soil Erosion and sediment Meshkindasht watershed to EPM method., Geography and Development Quarterly, vol,11. No. 30, 87-100.

Ahmadi, H., (2011): Applied Geomorphology (Water Erosion). 1(7) University of Tehran Press, Tehran, Iran.

Ahmadi. H., J. Ghodoosi. B. Mohseni,. R. Tahmasebi (2011): Assessing the accuracy and effectiveness of models for EPM, MPSIAC, geomorphology and hydro estimation of erosion and sedimentation basin province Kasilian. Geography and Development Quarterly, 9 (22): 107-127.

Amiri. F. (2010): Compression of Efficiency of MPSIAC and EPM Models to Estimate Soil Erosion and sedimented Yield (Case Study: Ghareh Aghach Watershed), Iranian Journal of Dynamic Agriculture, Issue 2.

Arekhi, S. and R. Nazari (2008): Zoning erosion intensity and sediment yield using MPSIAC in GIS (Case study: Ilam catchment). Jornal of Iranian Water Research, 2 (3): 77-81.

Barovic, G., Silva, M. L. N., Batista, P. V., G., Vujacic, D., Souza, S. W., Avanzi, J. C., Behzadfar M., Spalevic, V. (2015): Estimation of sediment yield using the IntErO model in the S1-5 Watershed of the Shirindareh River Basin, Iran. Agriculture and Forestry (61): 3: 233-243.

Blinkov, I. and Kostadinov, S. (2010): Applicability of various erosion risk assessment methods for engineering purposes, BALWOIS 2010 Conference - Ohrid, Republic of Macedonia. 25 - 29 May 2010. 
Behzadfar, M. Tazioli, A., Vukelic-Shutoska, M., Simunic, I., and Spalevic, V. (2014): Calculation of sediment yield in the S1-1 Watershed, Shirindareh Watershed, Iran. Agriculture and Forestry, 60 (4): 207-216.

Curovic, M., Spalevic, V., Dozic, S., Dubak, D. (1999): Proposal of Anti Erosion Regulation of Department 17 of Husbandry Unit Rudo Polje-Kovren. Agriculture and Forestry 45 (3-4): 5-23.

Fanetti, D., Vezzoli, L. (2007): Sediment input and evolution of lacustrine deltas: The Breggia and Greggio Rivers case study (Lake Como, Italy). Quaternary International, 173-174, 113-124.

Fustic, B, Spalevic, V. (2000): Characteristics of Erosion Processes of the drainage Basin of the Dapsic River. Agriculture and Forestry 46 (1-2): 5-17.

Gavrilovic, S. (1972): Inzenjeringo bujicnim tokovima i eroziji (Engineering of torrents erosion) (in Serbian). Izgradnja, Belgrade, Special edition.

Ghodoosi, J. (2002): Global pattern in watershed management. National Conference of Field Management- Soil Erosion and Development Arak: Central Province Agricultural Research and Natural Resource Center Iran.

Hadley, R. F. (1984): Measuring and Predicting Soil erosion. In, R. F. Hadley and D.E. Walling. Eds. Erosion and sediment yields some methods of measurement and modeling. Geo Books, Norwich. UK. 1-14.

Hessel, R. and Jetten, V. (2007): Suitability of Transport Equations in Modelling Soil Erosion for a Small Loess Plateau Catchment. Engineering Geology, 91, 56-71.

Kavian, A., Gholami, L, Mohammadi, M., Soraki, M, and Spalevic, V. (2018): Application of Wheat Residual Amounts on Soil Erosion Processes. Notulae Botanicae Horti Agrobotanici Cluj-Napoca. 46(2): 553-562.

Khodabash. S., (2010): Comparison of erosion and sediment yield estimation in Sezar sub basin (Dez drainage basin) by MPSIAC and EPM empirical methods, using GIS, Iranian Journal of Geology, Issue 12.

Kostadinov S., Zlatic M., Dragicevic S., Novkovic I., Kosanin O., Borisavljevic A., Lakicevic M., Mlađan D. (2014): Anthropogenic influence on erosion intensity changes in the Rasina River watershed - Central Serbia. Fresenius Environmental Bulletin 01/2014; 23(1a): 254-263.

Malekian. A., M. Dehghani. H. Ghasemi., (2012): Priority Places reduce flood and erosion control operations using fuzzy logic (Case Study: Watershed Fourg), Journal of Watershed Management Research. 66 (1): 73-88.

Milevski, I. (2008): Estimation of Soil Erosion Risk in the Upper Part of Bregalnica Watershed-Republic of Macedonia, Based on Digital Elevation Model and Satellite Imagery, $5^{\text {th }}$ International Conference on Geographic Information System (IGIS) 2-5 July 2008 at Fatih University in Istanbul, Turkey.

Rafahi, H., (1999): Water Erosion and Conservation, 5th Edition, University of Tehran Press, Tehran, Iran.

Rastgou, S. Ghahraman, B. Sanaei Nejad, H. Davari, K. \& Khodashenas, S.R. (2006): Estimation of erosion and sediment in the Tangh Konesht basin by PASIAC and EPM models using by GIS. Journal of science and Technology of agriculture and natural Resources, Vol. 10, No. 1, PP. 91-105.

Ristic, R., Radic, B., Vasiljevic, N. and Nikic, Z. (2011): Land use change for flood protection - a prospective study for the restoration of the river Jelasnica watershed. Bulletin of the Faculty of Forestry103: 115-130.

Spalevic, V., Lakicevic, M., Radanovic, D., Billi, P., Barovic, G., Vujacic, D., Sestras, P., Khaledi Darvishan, A. (2017a): Ecological-Economic (Eco-Eco) modelling in the 
river basins of Mountainous regions: Impact of land cover changes on sediment yield in the Velicka Rijeka in Montenegro. Notulae Botanicae Horti Agrobotanici Cluj-Napoca: 45(2):602-610.

Spalevic, V., Radanovic, D., Skataric, G., Billi. P., Barovic, G., Curovic, M., Sestras, P., and Khaledi Darvishan A. (2017b): Ecological-Economic (Eco-Eco) modelling in the mountainous river basins: Impact of land cover changes on soil erosion. Agriculture and Forestry, 63 (4): 9-25.

Spalevic, V., Barovic, G., Fikfak, A., Kosanovic, S., Djurovic, M., and Popovic, S. (2016): Sediment yield and Land use changes in the Northern Montenegrin Watersheds: Case study of Seocki Potok of the Polimlje Region. Journal of Environmental Protection and Ecology: 17 (3): 990-1002.

Spalevic, V., Behzadfar, A., Tavares, A. S., Moteva, M., Tanaskovik, V. (2016). Soil loss estimation of S7-2 catchment of the Shirindareh watershed, Iran using the river basin model. Agrofor International Journal, 1 (1): 113-120.

Spalevic, V., Curovic, M., Tanaskovic, V., Djurovic, N., Lenaerts, T. and Nyssen, J. (2015): Application of the IntErO model for the assessment of the soil erosion intensity and runoff of the river basin Dragovo Vrelo, Montenegro. Turkish Journal of Agricultural and Natural Sciences, Special Issue: 1072-1079.

Spalevic, V., Radanovic, D., Behzadfar, M, Djekovic, V., Andjelkovic, A., Milosevic, N. (2014): Calculation of the sediment yield of the Trebacka Rijeka, Polimlje, Montenegro. Agriculture and Forestry, 60 (1): 259-272.

Spalevic, V., Hübl, J. Hasenauer, H. and Curovic, M. (2014): Calculation of soil erosion intensity in the Bosnjak Watershed, Polimlje River Basin, Montenegro. The 5th International Symposium “Agrosym 2014”, Jahorina, 23-26 October 2014, Bosnia and Herzegovina, p 730-738.

Spalevic, V., Railic, B., Djekovic, V., Andjelkovic, A., and Curovic, M. (2014): Calculation of the Soil Erosion Intensity and Runoff of the Lapnjak watershed, Polimlje, Montenegro. Agriculture and Forestry, 60 (2): 261- 271.

Spalevic, V., Curovic, M., Simunic, I., Behzadfar, M, Tanaskovic, V. (2014): Land degradation, land use and soil erosion: the case of Montenegro. Watch Letter: Land Issues in the Mediterranean Countries 28 (1), 58-62.

Spalevic, V., Simunic, I., Vukelic-Sutoska, M., Uzen, N., Curovic, M. (2013a): Prediction of the soil erosion intensity from the river basin Navotinski, Polimlje (Northeast Montenegro). Agriculture and Forestry, 59 (2): 9-20.

Spalevic, V., Djurovic, N., Mijovic, S., Vukelic-Sutoska, M., Curovic, M. (2013b): Soil Erosion Intensity and Runoff on the Djuricka River Basin (North of Montenegro). Malaysian Journal of Soil Science. 17: 49-68

Spalevic, V., Grbovic, K., Gligorevic, K., Curovic, M., and Billi, P. (2013c): Calculation of runoff and soil erosion on the Tifran watershed, Polimlje, North-East of Montenegro. Agriculture and Forestry, 59 (4): 5-17.

Spalevic, V., Curovic, M., Uzen, N., Simunic, I., Vukelic-Shutoska, M. (2013d): Calculation of soil erosion intensity and runoff in the river basin of Ljesnica, Northeast of Montenegro. In proceeding of the 24th International Scientific-Expert Conference on Agriculture and Food Industry, Sarajevo, Bosnia and Herzegovina.

Spalevic, V., Curovic, M. Tanaskovik, V., Oljaca, M., Djurovic, N. (2013e): The impact of land use on soil erosion and run-off in the Krivaja river basin in Montenegro. The First International Symposium on Agricultural Engineering, 4th - 6th October 2013, Belgrade-Zemun, Serbia, VI: 1-14. 
Spalevic, V., Curovic, M., Borota, D. and Fustic, B. (2012a): Soil erosion in the river basin Zeljeznica, area of Bar, Montenegro. Agriculture and Forestry, 54 (1-4): 524.

Spalevic, V., Mahoney, W., Djurovic, N., Üzen, N. and Curovic, M. (2012b): Calculation of soil erosion intensity and maximum outflow from the Rovacki river basin, Montenegro. Agriculture and Forestry, 58 (3): 7-21.

Spalevic, V. (2011): Impact of land use on runoff and soil erosion in Polimlje. Doctoral thesis, 260p, Faculty of Agriculture of the University of Belgrade, Serbia.

Spalevic, V., Curovic, M., Povilaitis, A., Radusinovic, S. (2004): Estimate of Maximum Outflow and Soil Erosion in the Biogradska River Basin. Monographs, No.1, Biodiversity of the Biogradska Gora National Park, ed. V. Pesic.pp. 1-20, Department of Biology of the University of Montenegro, Podgorica.

Spalevic, V., Spalevic B, Fustic, B, Popovic, V, Jovovic, Z, Curovic, M. (2000a): Characteristics of Erosion Processes and Proposal of measures of Land Reclamation in Upper Part of the Sekularska River drainage basin. Agriculture and Forestry, 46 (3-4): 15-28.

Spalevic, V., Dlabac, A., Spalevic, B., Fustic, B., Popovic, V. (2000b): Application of Computer-Graphic Methods in Studying the Discharge and Soil Erosion Intensity - I Programme "River Basins". Agriculture and Forestry, 46 (1-2): 19-36.

Spalevic, V., Dubak, D, Fustic, B, Jovovic, Z, Ristic, R. (1999): The Estimate of the Maximum Outflow and Soil Erosion Intensity in the Kaludra River Basin. Acta Agriculture Serbica, 4 (8): 79-89.

Tangestani, M. (2006): Comparison of EPM and PSIAC models in GIS for erosion and sediment yield assessment in a semi-arid environment: Afzar catchments, Fars Province, Iran. Journal of Asian earth sciences, vol.27, P.585- 597.

Tazioli, A. (2009): Evaluation of Erosion in Equipped Basins: Preliminary Results Comparison Between the Gavrilovic Model and Direct Measurements of Sediment Transport, Environ Geol, Vol. 5, No. 56: 825-831.

Tazioli A., Mattioli A., Nanni T., Vivalda P.M. (2015): Natural hazard analysis in the Aspio equipped basin. Engineering geology for Society and Territory, Vol. 3:431535. Doi 10.1007/978-3-319-09054-2_98.

Vujacic, D., Barovic, G., Djekovic, V., Andjelkovic, A., Khaledi Darvishan, A., Gholami, L., Jovanovic, M. and Spalevic, V. (2017): Calculation of Sediment Yield using the "River Basin" and "Surface and Distance" Models: A Case Study of the Sheremetski Potok Watershed, Montenegro. Journal of Environmental Protection and Ecology, 18(3): 1193-1202.

Vujacic, D., Spalevic, V. (2016): Assessment of Runoff and Soil Erosion in the Radulicka Rijeka Watershed, Polimlje, Montenegro. Agriculture and Forestry, 62 (2): 283-292.

Vujacic, D., Barovic, G., Tanaskovik, V., Kisic, I., Song, X., Silva, M. L. N. and Spalevic, V. (2015). Calculation of runoff and sediment yield in the Pisevska Rijeka Watershed, Polimlje, Montenegro. Agriculture and Forestry, 61 (2): 225234. 